\title{
WOMEN PERIODICALS IN THE NEW WOMAN PRINT CULTURE OF FIN-DE-SIÈCLE BRITAIN ${ }^{1}$
}

\author{
Carme Font Paz, Universitat Autònoma de Barcelona \\ Email: Carme.Font@uab.cat
}

\begin{abstract}
The 1890s saw an increasing feminization of the literary marketplace, as more than a hundred novels representing the 'New Woman' defying the conventional Victorian marriage plot and values were published. Contemporary print culture was aware of the emergence of a type of woman who was educated, independent-minded, and eager to consume both fiction and journalism. Focusing on four long issues of the magazine Womanhood (1894-1904), this article will explore the ways it departed from 'family' papers and emerged as an outlet for much of the New Woman thought. Womanhood sought to change the reading strategies of women by empowering them to gain a critical and crucial knowledge of social realities. Thus, 'New Woman' did not necessarily construct a gender identity in relation to the text, but developed a knowledge and empowerment of the female self by the act of reading print culture and novels in a new light.
\end{abstract}

Keywords: New Woman; Womanhood; Fin-de-siècle; Print Culture; Selfhood.

Title in Spanish: Periódicos femeninos de la cultura editorial de la Nueva Mujer en la Gran Bretaña de fin de siglo

Resumen: La década de 1890 fue testigo de una creciente feminización del mercado literario con la publicación de más de un centenar de novelas que representaban a la 'Nueva Mujer' desafiando a la trama convencional victoriana y sus valores. La cultura impresa contemporánea era consciente del emerger de una clase de mujer cultivada, independiente y ansiosa por consumir obras de ficción y periodismo. Este artículo se centra en cuatro números de la revista Womanhood (1894-1904) para explorar el modo en que sus contenidos se distanciaban de los periódicos "familiares" y se erigían como baluartes del pensamiento de la Nueva Mujer en el Reino Unido. Womanhood buscaba cambiar las estrategias de lectura de las mujeres capacitándolas para obtener un conocimiento crítico y crucial de las realidades sociales. De este modo, la Nueva Mujer no construía necesariamente una identidad de género en relación al texto, sino que desarrollaba un conocimiento y capacitación de la esencia femenina por el mero hecho de leer novelas y artículos bajo un prisma distinto.

Palabras Clave: Nueva Mujer; Womanhood; Fin-de-siècle; Cultura impresa; identidad del yo.

Very few women in the year 1900 were aware of the fact that "when hairs become really noticeable, there is nothing that can safely be done except to have them destroyed by electrolysis, which consists in inserting a very fine needle which forms one terminal of a

Date of reception: 14 June 2011

Date of acceptance: 25 August 2011 
constant current battery right down to the base of the follicle" ${ }^{\text {, }}$, but even less women would imagine now that such depilatory wisdom was known, written about and published for a female middle-class generalist audience. Its readers formed a loose community of women who, in their willingness to think and act independently from their late Victorian mothers, brought about an increasingly feminization of the literary marketplace, through which more than a hundred novels representing a 'New Woman' were published. At the same time, contemporary print culture became aware of the emergence of a type of woman who was educated, independent-minded, and eager to consume both fiction and journalism. Ledger and Luckhurst consider that New Woman entered the vocabulary as a popular term in the mid-1890s, specifically in a pair of articles by Sarah Grand ${ }^{3}$ entitled "The Modern Girl" and published in the North American Review (June 1894:706-714), which quickly became a familiar phrase in the journalistic vernacular of the day, and made regular appearances in periodical articles throughout the last decade of the nineteenth century" (Ledger, Luckhurst 2000:75). The New Woman was thus gaining force both in print and in real life.

The thought, fiction and journalism of the 'New Woman' came as a result of a profound dissatisfaction with traditional Victorian roles for women. Pioneering authors such as Olive Schreiner with her Story of an African Farm (1883) and a number of modest household names like Ella Hepworth Dixon and Mona Caird ${ }^{4}$-who are just now receiving renewed publishers' attention with updated editions of their main works- raise basic questions about what is a woman and what should be expected from her. Dixon, in her largely biographical work The Story of a Modern Woman (1894), considered that "the Self was too multi-faceted as to be represented in its entirety" (Fehlbaum 2005:3), and believed this New Woman to be a product of her own times -hinting in this way at a vague concept of the modernist artist. Therefore the traditional notions about education, work, and sexuality were seen as becoming inevitably obsolete:

The life of Mary Erle, like that of many another women in the end of the nineteenth century, had been more or less in the nature of an experiment. Born too late for the simple days of the fifties, when all it behoved a young girl to do was to mind her account-book, read her Tennyson, show a proper enthusiasm for fancy-work stitches, and finally, with many blushes, accept the hand of the first young man who desired to pay taxes and to fulfil the duties of a loyal British subject (and the young man, it must be remembered, in the middle of this century, actually did both), Mary was yet too soon for the time when parents begin to take their responsibilities seriously, and when the girl is sometimes as carefully prepared, as thoroughly equipped, as her brother for the fight of life. A garden full of flowers, a house full of books, scraps of travel: these things were her education. (Dixon 1894:5)

Written in a vindictive tone, but not necessarily in a revolutionary one, the New Woman short-lived current is sometimes compared to the decadent avant-garde movement of the

\footnotetext{
2 See Womanhood: The Magazine of Women's Progress and Interests. Vol. III -No 14. December 1900.

3 Sarah Grand (1854-1943), Anglo-Irish writer and main exponent of the less radical or "puritan" branch of New Woman fiction. Her main works were The Heavenly Twins (1893) and The Beth Book (1893).

4 Mona Caird (1854-1932), The Daughters of Danaus (1894). She was a novelist and essayist active in the suffragist movement.
} 
1890's -especially for their shared concept of sexuality; but there is a wide consensus that the New Woman was a cultural phenomenon made possible by the burgeoning women's movement of the late Victorian period. It would essentially be, then, a dissatisfied by-product of late Victorianism and even a natural precursor of the golden years of suffragettism because of its capacity to include contemporary political concerns in a wide-ranging agenda for women.

\section{THE IDENTITY OF THE NEW WOMAN}

As a result of this ideological width, the identity of the real and the fictional New Woman was not, and could not be, homogeneous. Her opponents were mainly conservative male authors, but also conservative women who wrote minor fiction or articles proclaiming the traditional Victorian female values of sacrificing motherhood and wifehood. Annie Swam, with 'what should women read?' in The Woman at Home (1896) or Eliza Linton, with her novel The One Too Many (1894), represented the archetypal New Woman as "a mannish overeducated bore (frequently a 'Girton Girl'5), as a bad mother (if not an embittered spinster), and as lacking in all the attributes usually associated with ideal Victorian womanhood" (Ledger, Luckhurst 2000:76). However, those women writers who were eager to promote the New Woman and her cause represented her as an intelligent, sensitive and sexually healthy person who had ambitions beyond marriage and motherhood. Kate Flint notes that "as in the case of sensation fiction, it is easy to identify the specific elements which made this fiction controversial, which ensured that writing about it led, in turn, to good journalistic copy" (Flint 1994:294). These elements basically include:

a) Protesting against the restrictive upbringing and education of girls.

b) Challenging the notion that marriage can be the only place for a woman to develop herself.

c) Vindicating the act of reading as being independent from content and, equally important, from the physical reactions of women readers.

d) Claiming a sound knowledge of the female body. Informed sexuality and access to higher education -and therefore, to a professional life- were considered essential attributes for New Women to gain material independence.

Nevertheless, Ann Ardis has argued that "underlying these issues the question of where sexuality figures into the whole of human character not only appears as central to New Woman novels, but links them with a proliferation of contemporary discourses discussing sexuality" (Ardis 1990:51). One of the most interesting and particular aspects of New Woman fiction lies in the relationship it establishes between sex, reading and knowledge. Unlike Romantic or sensation novels, New Woman fiction and short pieces "expect that its readers take the actual activity of reading seriously, however much their attention might be claimed by the nature of the subject-matter" (Flint 1994:295). The novels, with their direct allusions to the reader and their abundant use of quotations, encouraged an inquiring manner

'Girton Girl' refers to women studying at Girton College at Cambridge University. 
of reading, "not just developing one's rational powers in relation to the printed word, but in relation to society more widely". (Flint 1994:296)

Although this emphasis on rationality and knowledge of the world does not rule out imagination, it clearly discourages a pre-eminence of emotion. What mattered in New Woman writing then, was the development of "writers' perceptions about the relationship between fictional texts and the society of their readers, and the ways in which they could be invited to use similar techniques when approaching both novels and their lives" (Flint 1994:315). In a very definite sense, then, New Woman fiction denied the interdependency of mind and body in the process of reading. If earlier in the century, women reading denoted 'frivolity', 'emotion' and spare time so that reading was seen as an activity which entertained the imagination and lower passions, New Woman reading was a path to obtain important knowledge of the world and the body, rather than an escape from social realities. With this kind of intellectual activity, women demonstrated that by choosing what to read, and understanding it, external control over the body by means of sensation, fantasy and emotion was weakened.

It was this emphasis on rationality and knowledge, as well as the call to education and the relationship between knowledge and reality, what raised fierce criticisms against New Woman fiction appearing in Punch (1890's) and Victorian conservative 'domestic' magazines. These women were seen as insensitive mothers and as enemies of the institution of marriage, as portrayed by the character Herminia in Grant Allen The Woman who Did (1895), a monogamous woman who avoids marriage and lives independently from her partner. When he dies, she has to cope with the challenge of raising her child alone, and begins to question her new-gained independence.

Most of all, New Woman writers such as Shreiner, Allen and Grand complained against the hypocrisy of enforced marriage, motherhood and the perils of sexual and intellectual ignorance. They did not, as might be expected, propose a parallel revolution to suffragettism. Theirs was a social movement interested in personal emancipation for women but it did not hoist political claims -although in some New Woman publications, such as Womanhood, the issue of franchise and suffragettism was indeed mentioned. In this sense, we could argue that the New Woman thought coexisted with political concerns regarding franchise for women, but it is more correct to argue that New Woman thought paved the way to "the growing feminist movement" (Flint) as we know it today and to the culminating years of suffragettism in the 1910s and 1920s:

During the nineteenth century the fundamental tenets of women's role were to be challenged in several ways: by attacking inequalities in marriage and family; by questioning the role motherhood played in women's lives; by challenging the very notion of masculinity to which the domestic conception of femininity had been set in opposition; and by opening up work and politics to women. (Phillips 2003:17).

\section{WOMEN READERS AND THEIR COMMUNITIES}

Equally important for the dynamics of the New Woman thought is the fact that it created and consolidated a community of woman readers "who could refer to these works as proof 
of their psychological, social, and ideological differences from men" (Flint 1994:305). Journals and magazines were essential to foster this community, and to present the ideas of the New Woman thought in its more modest and radical manifestations. The monthly magazine Womanhood: The Magazine of Women's Progress and Interests (1894-1904) is a good case in point. It was edited - or 'conducted'- by Mrs Ada S.Ballin', and its solid contribution -50 pages per issue- to the New Woman agenda challenged family and domestic papers and their serials of sensation stories. ${ }^{7}$

Womanhood's target audience was a notion of the educated woman but, unlike traditional publications geared towards the domestic and the feminine public, Womanhood exposed many achievements by women in several areas, some of them traditionally restricted to men. In a formal, frank and celebratory tone, in which writers sometimes addressed readers in the second person, this journal did not tell women what they were but what they could do, and which possibilities lay ahead for them. It whispered progress to them, as Ballin made it clear in one of the first issues of the magazine:

I intend to devote the pages of Womanhood to subjects which appeal more especially to intellectual and highly educated women; and to supply them with a more solid literary diet than other papers offer. At the same time, the political interests of women will be by no means neglected. One of the most important features will be on hygiene, personal health and beauty culture. I am the authority in the latter department. (Womanhood 1898:Dec,iii)

Although Womanhood devoted many pages (20 per cent in some of its issues) to 'personal health and beauty culture', the approach to these matters was not frivolous, but overtly serious and with a scientific framework in mind. For instance, Mrs Ballin writes in her article 'The Care of the Mouth and Teeth' that 'acids, natural to the mouth or produced by food, gradually work their way through the external flint-like covering of the tooth, till they reach the ivory-lie material called dentine, which constitutes the inner portion of the tooth; tiny microscopic organisms assist the process, acting in conjunction with the acid" (Womanhood 1899:Dec.22). The three-page long article provides detailed explanations on recipes to avoid teeth decay and gum pain. The expositive tone and the scientific jargon that is used looks surprising even to the modern reader, if one takes into account that Ballin was neither a doctor nor a chemist. The various articles on beauty issues considered from a scientific and rational point of view attest to the fact that the editor and writers of Womanhood had a clear agenda in mind: to elevate the rudiments of beauty, traditionally considered as feminine and frivolous, into scientific objects of study.

\footnotetext{
$6 \quad$ Ada Ballin was a professional journalist and published author, she was married but chose to work under her maiden name, being true to her feminist inclinations. Besides Womanhood, she edited two other publications, Baby: The Mother's Magazine, and Playtime, a children's magazine.

7 Richard Altick in The English Common Reader writes that "the most widely circulated periodicals, apart from the weekly newspapers, were the 'family' papers meant for the indifferently educated reader. Among these, the two which had led the field in the fifties retained their supremacy down into the eighties. The staple of both the Family Herald and the London Journal was short stories and full-length novels. [...] They avidly consumed, year after year and decade after decade, fiction dealing with the aristocracy of wealth and blood, whose lives were crammed with crises and no little sin". (Altick 1957:360)
} 
It is precisely this eagerness to explain, to inform, to illumine and to rationalize what makes every article in Womanhood an immersion under the rough waters of early modernist feminist thought. Its articles on marriage, family, and the relation between the sexes make it very clear that the New Woman is an emancipated individual who may or may not reject marriage and motherhood but who, in either case, expects to be able to relate to men on an equal basis. And it is precisely in this area where we find, as in the rest of New Woman literature, divergent opinions. Normally, Womanhood approached the more radical viewpoints on marriage in commentary or opinion articles, whereas the most moderate views on the 'relation between the sexes' were expressed under the agency of short fiction stories. Thus, in The Tragedy of Silence, Lilian Quiller writes a short story on a couple who stops talking to each other because they feel incapable of healing their ill son. Effectively, although perhaps not brilliantly, Quiller exposes the common problems of communication and resentment within couples:

So the years passed by. Silent -always silent. And if at some moments the heart of one would soften, the heart of the other would be hard; and the silent child grew up in the midst of silence, and knew no other life (Quiller, Womanhood,1899:Dec.8)

After twenty years the son dies, the married couple bursts into tears, and starts to express their love to each other. Although the end is traditional and could have sounded very frustrating even to New Woman ears, the theme of lack of communication and the ensuing hostility between partners was a delicate one to tackle. It also reflects an openness and frankness towards intimate matters which was rather uncommon. But maybe more importantly, it makes both men and women responsible for the failed marriage and its eventual success. Perhaps women cannot escape an unhappy union, but they are not more responsible than men for this dejection.

A similar note is played in a more vindictive but cleverly opinion article written by Beatrice Lewis, entitled "Should Men Break Engagements?" Contrary to common opinion, Lewis strongly argues that men should be free from social condemnation if they break their engagements after realising their fiancée is inappropriate or undesirable for them: "As the conventions rule at present, those effecting engagements to marry form perhaps the only point in social life where the free will of men is more crippled by public opinion than that of women" (Lewis, Womanhood 1900:Dec.88). She believes that this convention is absurd because "two wrongs don't make a right", but, at the same time, she convincingly notes that "this argument [that men should not break engagements] is based upon the assumed universal desire of womankind to get married at any cost, to anybody; and holds that anything which baulks her in that all important object does her an irremediable wrong". Instead of adopting a radical stance defending or condemning the breaking of engagements on moral grounds, Lewis considers the issue from a sexual point of view: since women are not objects, and do not believe their ultimate goal in life is marriage, they are not eager to accept an unhappy union; and since they are not inferior to men, they should never accept an unequal treatment in this area which is apparently unfair to men but is, in reality, equally unfair to women. The New Woman message in the marriage agenda could not be better expressed: clear, vindictive without being aggressive, and sensible. 


\section{THE CONCERNS OF THE NEW WOMAN}

Another significant and original area in New Woman thought, which found abundant echoes in Womanhood in its reports, fiction stories and opinion pieces, was education and work. Instead of focusing on primary formal education and its reforms, Womanhood writers put the emphasis on higher and university education in the section "What women are doing at home and abroad". In them, reports from Germany, Wales, Ireland or France by native 'correspondents', told of new opportunities for women at universities, academic institutions, and highly professional jobs in the legal, scientific or artistic fields which, although minority, were by no means scarce. Womanhood was particularly eager to show its readers that professional achievements were available to women if they "remained independent in thought" and worked hard. "I learned that in the first professional examination in medicine, Miss Isabel Mitchell was the only candidate, either male or female, to earn 'distinction' in chemistry", wrote Aitken. "The same coveted designation was also won in zoology, materia medica, and medical jurisprudence by other women medical students, and first class honours in English by several in the department of arts [...] But in all these apparently more serious matters, the realm of art must not be neglected, for of what ultimate use is all our brain-work and triumph of philosophy if we lose the cunning of the hand and eye?" (Aitken, Womanhood, 1899:Dec.26). The author, after presenting a number of achievements in the fields of law and medicine, seems to forget further advancements in the Arts, as if she wished to put the emphasis on the 'rational and the scientific', realms which were traditionally vetted to women.

At the same time, correspondent Frau Kober explains in her "What the Women are Doing in Germany" that "much has been done in the Fatherland during the past few years to make the thorny path of study easier for the average girl. Formerly there failed the connecting-link between a girl's finishing school and university study, even after the last-named institutes had reluctantly opened their doors to the sex" (Kober, Womanhood, 1899:Dec.28) which gives some idea to contemporary -and modern- female readers of how the woman question in the realm of education was advancing in other parts of Europe. However explicit the article is, it does not condemn lack of university opportunities in Germany, it only exposes them. It is precisely the objective-rational tone of much of the New Woman fiction and writing which seems to invest it with a 'commonsensible voice of truth' that appealed to women readers -the length in content and time are proof enough of a faithful and receptive audience.

But New Woman writers concerned with education did not restrict their focus on university studies. Although they targeted an 'educated woman', they also knew that many women would neither have the brains nor the means to enter higher education. For this reason, New Woman writers also encouraged appropriate training and professionalisation of trades, particularly those in which women participated. Lectures on the "Union of Typists" working in cities, and on "women and the Factory Acts", for example, were often given in Wales, Ireland and England to "furnish information in the most direct and simple manner possible on the more clamant subjects connected with the employment of women and children, and the laws relating to such, about which there is usually the densest ignorance prevailing" (Aitken, Womanhood, 1899:Dec.27). 
Womanhood, as most of the New Woman journals and publications, was careful not to shout political matters like, for instance, women suffrage. In fact, as the above quotation shows, issues such as child work were only superficially mentioned or treated. However, Womanhood writers had political opinions and concerns of their own, and tried to voice them in a subdued but clear way. For instance, we repeatedly find military references in the reports about developments in the second Boer war and, more importantly, about the contribution of women to that war or wars in general. In the short editorial piece "Women and war", we read about the relief efforts by middle and upper-class women, including nursing help like that of Florence Nightingale. "Women have come to the fore, as they generally do, to give all assistance possible in order to mitigate the horrors of the war from which we are all now suffering" (Womanhood 1899:Dec.52).

Although the intention of these reports is not primarily patriotic, they try to extol the participation of women in the war effort: relief operations are as important an effort as war action. At times, though, the political message is more bellicose and presents a metaphorical picture of women as warriors. This is the innuendo in "A Woman Warrior of the Past: Semiramis", where two pages are devoted to the military condition of these Syrian women warriors of antiquity. Wrapped in a halo of mysticism, the nevertheless factual tone of the article describes this warrior as a skilful woman who surpasses men in climbing mountains, in courage and in sagacity. Besides, her husband admires her for these and other qualities which are not conventionally "feminine". The author F.C. Ireland, B.Sc, further writes: "Ambition seemed to be the predominant feature of her character. No risk was thought to be too considerable, no expense so extravagant, no trouble too prodigious to secure distinction and impress her contemporaries with a sense of her greatness and to leave the traces of her magnificence for the study and wonder of an admiring posterity" (Ireland, Womanhood, 1900:Feb.130).

The image of this powerful Goddess of war, invested with insurmountable ambition and recklessness, acts as a mind-trigger for much of the New Woman thought: women can do whatever they wish and can, their health and their talents being the only limitations to their self-realisation. They are also prepared for glory if they are so gifted. Sometimes, these talents will resonate with the conventional qualities expected from women (nursing, social work, writing or teaching). In other occasions, these gifts will be similar to those men cherish so much in themselves: a passion for fighting, ambition, sports, doing business, or practicing law. Although sometimes New Woman writers differed on what qualities made a woman extraordinary, female thinkers of the period, like Sarah Grand, considered that women should not underestimate themselves for excelling in 'traditional women labours'. Differences between the sexes were largely accepted within New Woman thought, but what Womanhood vindicated was the capacity of women to excel in whatever gifts they choose to show, and the need for society to recognise this. For instance, in a biographical report on Sara Grand, we read

She [Sarah Grand] is in herself a proof that it is generally the most highly educated of her sex who are most refined. She holds the highest opinions on this point, and maintains, earnestly, and on all occasions, that there is no reason why women who have attained much knowledge should lose any of the charm of their feminine attributes, and that culture 
should not only stimulate them to increased efforts to stand by each other at all times and seasons, but also to preserve each in herself, in all its strength and glory, the respect and reverence due to womanhood. (Mrs Helen Black, Womanhood: Feb.1900)

Again, if the motto of New Woman thought was knowledge and education as a clue to freedom and 'refinement' of ideas, the agency of this crucial knowledge lay in the act or reading.

Each issue of Womanhood devoted several pages to the section "What to read", but unlike the usual reading sections ripe with recommendations of novelties, New Woman thought included lengthy critical commentary of works which were learned or academic (Chaucer, medicine tracts, German romanticism or Italian humanism) and personal notes on how a particular woman or communities of women could relate to the work under review. For instance, in the December 1899 issue of Womanhood, we find a detailed critical commentary on Italian classical literature side by side with a benevolent criticism of Fable and Song in Italy, an academic work on the subject written by a Miss Clerke who, apart from her scholarly research, translated some of the fables into English. "First, I trace out some of the influences acting on the more popular forms of Italian song; and secondly, to offer to English readers, in the shape of translated extracts, specimens of Italian poets whose works difficulties of language have hitherto rendered them inaccessible to the general public".

The section "What to read" was a critical exercise aimed at showing, on the one hand, women's scholarship and understanding of literature and, on the other, a complete disregard for 'recommended' reading in the conventional sense of the word. What mattered was not to read the 'right' kind of books, but "the thought which goes into reading them" (Flint 1994:308). It was the experience of reading, then, and of experiencing life events in first person, what mostly characterised New Woman authors. Above all, "readers were encouraged to apply the criteria that they would use when reading a novel to the society around them" (Flint 1994:315), and this is precisely what the editorial philosophy of Womanhood was about: its emphasis on the idea that women should read thoughtfully and critically, and act on what they learn, created a community of women readers who was soon prepared to understand, afterwards, authors like Rebecca West and magazines such as The New Freewoman (founded in 1913) with their political messages on franchise, suffragettism and the full emancipation of women.

Although the importance of suffragettes and suffragist literature has long been recognized as a turning point in modern Feminist tendencies, the short span of New Woman thought has precluded a solid evaluation of its influence in the configuration and origins of suffragettism itself. "Their writers laid the foundations for later twentieth-century feminist criticism, and they looked back to the New Woman novelists as representing an important development, since they typified the fact that women writers were no longer playing the 'sedulous ape', imitating as nearly as possible the method, but above all the point of view of man". (Flint 1994:314)

Perhaps New Woman thought and fiction has been relatively scarcely studied-compared to other currents of late Victorian and early Modernist literature- for its mimetic capacity to join knowledge, independent thought and action, and therefore to combine its imminent suffragist thought with its emphasis on women emancipation and rebellion. It is, then, 
when we seem to forget that the history of women's adulthood has been painful and long, that reading a few pages of Womanhood can remind us of the fact that thought has always preceded political action.

\section{REFERENCES}

Altick, R. D. 1998. The English Common Reader: A Social History of the Mass Reading Public 1800-1900, Columbus: Ohio State University Press.

Ardis, A. 1990. New Women, New Novels: Feminism and Early Modernism, New Jersey: Rutgers University Press.

Barrell, J.; Braithwaite, B. 1988. The Business of Women's Magazines, London: Kogan Page.

Cunningham, A. R. "The New Woman Fiction of the 1890's". Victorian Studies, Vol.17:2. Dec.1973:177.

Dixon, E. H.; Fenlbaum, V. (ed). 2005. The Story of a Modern Woman, London; Ashgate.

Dowling, L. "The Decadent and the New Woman in the 1890's", Nineteenth-Century Fiction, Vol.33, No.4. Mar.1979:434-453.

Fuint, K. 1994. The Woman Reader 1837-1914, New York: Oxford University Press.

Gardiner, J. (ed). 1993. The New Woman, Women's Voices 1880-1918, London: Collins \& Brown.

Grand, S. "The Modern Girl”, North American Review (June 1894): 706-714.

Heilmann, A. 2004. New Woman Strategies, Manchester: Manchester University Press.

Ledger, S.; Luckhurst, R. 2000. The Fin de Siècle: A Reader in Cultural History c. 1880-1900, London: Oxford University Press.

Ledger, S. 1997. The New Woman, Fiction and Feminism at the fin-de-siecle, Manchester: Manchester University Press.

Marks, P. 1990. Bicycles, Bangs and Bloomers: The New Woman in the Popular Press, Lexington: University Press of Kentucky.

PHILLIPS, M. 2003. The Ascent of Woman: The History of the Suffragette Movement and the Ideas behind it, London: Little Brown.

Richardson, A. (ed). 2000. The New Woman in Fiction and in Fact: Fin-de-siecle Feminisms, Basingstoke: Palgrave in association with Institute for English Studies, University of London.

Womanhood: The Magazine of Women's Progress and Interests. Vol. III -No 12. December 1898. 
Womanhood: The Magazine of Women's Progress and Interests. Vol. III -No 13. December 1899.

Womanhood: The Magazine of Women's Progress and Interests. Vol. III -No 14. February 1900.

Womanhood: The Magazine of Women's Progress and Interests. Vol. III -No 15. December 1900. 